\section{Orbital Fat Prolapse}

Leonid Skorin Jr, DO, OD, MS; Stephanie Norberg, OD
From the Mayo Clinic Health

System in Albert Lea Minnesota (Dr Skorin), and the Minneapolis VA Health System

in Minnesota (Dr Norberg).

Financial Disclosures:

None reported.

Support: None reported.

Address correspondence to Leonid Skorin Jr, DO, OD, MS

Mayo Clinic Health System in

Albert Lea, 404 W Fountain St,

Albert Lea, MN 56007-2437.

Email: skorin.leonid@mayo.

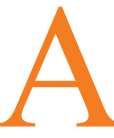

79-year-old man presented with an asymptomatic yellowish mass on his

temporal bulbar conjunctiva of the left eye. The patient's visual acuity was unaffected, and he had no history of ocular trauma, surgery, or thyroid dysfunction. Ocular examination revealed a soft, yellow, nontender mobile mass. Subconjunctival herniated orbital fat (HOF), also known as intraconal fat prolapse (image $\mathbf{A}$, arrow), was diagnosed. The patient also had bilateral inferior and superior medial eyelid festoons, also known as extraconal fat prolapse (image $\mathbf{B}$, arrows). The subconjunctival HOF was surgically removed. The patient declined blepharoplasty to remove the extraconal fat protrusion.

Extraconal fat prolapse is common, but subconjunctival HOF, which is benign, is rare. ${ }^{1,2}$ Patients may present with symptoms of dry eyes, discomfort, or cosmetic complaints. ${ }^{1,3}$ Clinically, subconjunctival HOF is typically located in the superotemporal quadrant and appears as a soft, yellow mass that is easily displaced using a cotton-tip applicator. ${ }^{3,4}$ These characteristics help distinguish it from conjunctival dermolipoma, conjunctival lymphoma, epidermoidal cyst, and prolapse of the lacrimal gland. ${ }^{1-4}$ Orbital computed tomography or magnetic resonance imaging identifies subconjunctival HOF as a low-density mass continuous with the intraconal fat. ${ }^{1,2,4,5}$ Histopathologic analysis reveals normal adipose tissue. $^{5}$ Subconjunctival HOF is managed using transconjunctival excision. ${ }^{1,5}$ Extraconal fat protrusion can be corrected with blepharoplasty. ${ }^{2}$ (doi:10.7556 /jaoa.2018.127)

\section{References}

1. Skorin L Jr, Rink C. Diagnosis and excision of subconjunctival herniation of orbital fat. Optom Vis Sci. 2014;91(9):e236-e240.

2. Monner J, Benito JR, Zayuelas J, Paloma V, Castro V, Serra JM. Transconjunctival herniation of orbital fat. Ann Plast Surg 1998;41 (6):658-661

3. Chatzistefanou KI, Samara C, Asproudis I, et al. Subconjunctival orbital fat prolapse and thyroid associated orbitopathy: a clinical association. Clin Interv Aging. 2017;12:359-366.

4. Wang $X$, Yan J. Subconjunctival orbital fat prolapse: an unsuspecting rare lesion. J Craniofac Surg. 2015;26(2):e92-e94.

5. Lin CC, Liao SL, Liou SW, Chen CC, Wu YY, Woung LC. Subconjunctival herniated orbital fat mimicking adipocytic neoplasm. Optom Vis Sci. 2015;92(10):1021-1026.

(๑) 2018 American Osteopathic Association

Keywords: extraconal fat prolapse, herniated orbital fat intraconal fat prolapse
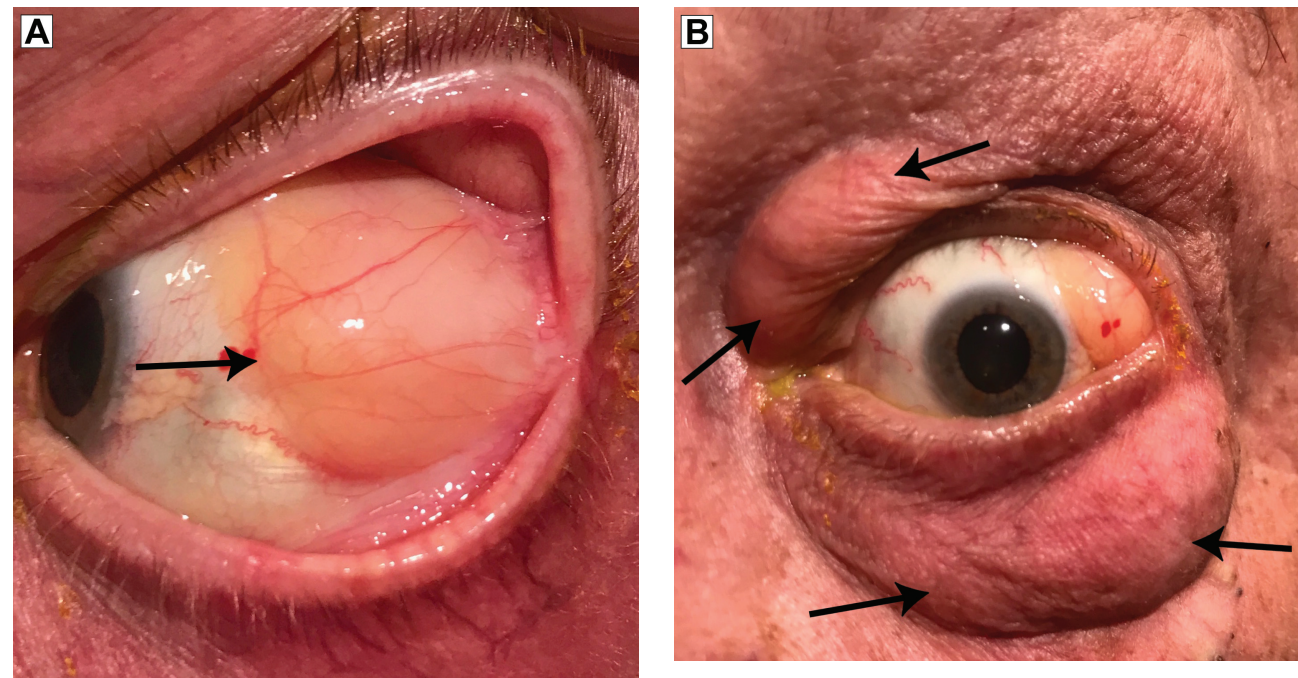